\title{
Ruegeria halocynthiae sp. nov., isolated from the sea squirt Halocynthia roretzi
}

\author{
Young-Ok Kim, ${ }^{1}$ Sooyeon Park, ${ }^{2}$ Bo-Hye Nam, ${ }^{1}$ So-Jung Kang, ${ }^{2}$ \\ Young Baek Hur, ${ }^{3}$ Sang-Jun Lee, ${ }^{1}$ Tae-Kwang $\mathrm{Oh}^{2}$ \\ and Jung-Hoon Yoon ${ }^{4}$
}

Correspondence Jung-Hoon Yoon jhyoon69@skku.edu

\author{
${ }^{1}$ Biotechnology Research Division, National Fisheries Research and Development Institute (NFRDI), \\ Gijang, Busan 619-705, Republic of Korea \\ ${ }^{2}$ Korea Research Institute of Bioscience and Biotechnology (KRIBB), PO Box 115, \\ Yusong, Daejeon, Republic of Korea \\ ${ }^{3}$ South East Sea Fisheries Research Institute, Tongyoung 650-943, Republic of Korea \\ ${ }^{4}$ Department of Food Science and Biotechnology, Sungkyunkwan University, Jangan-gu, Suwon, \\ Republic of Korea
}

The genus Ruegeria was proposed by Uchino et al. (1998) based on the reclassification of Agrobacterium atlanticum, Agrobacterium gelatinovorum and Roseobacter algicola as Ruegeria atlantica, Ruegeria gelatinovora and Ruegeria algicola, respectively. However, Ruegeria gelatinovorans corrig. was subsequently reclassified as Thalassobius gelatinovorus (Arahal et al.,2005) and Ruegeria algicola was moved to a new genus, Marinovum, as Marinovum algicola (Martens et al., 2006). Recently, Silicibacter lacuscaerulensis (Petursdottir \& Kristjansson, 1997) and Silicibacter pomeroyi (González et al., 2003) were transferred to the genus Ruegeria as two different species (Yi et al., 2007), and five more Ruegeria species, Ruegeria mobilis (Muramatsu et al., 2007), Ruegeria pelagia (Lee et al., 2007), Ruegeria scottomollicae (Vandecandelaere et al., 2008), Ruegeria marina (Huo et al., 2011) and Ruegeria faecimaris (Oh et al., 2011), have been described. However, it

The GenBank/EMBL/DDBJ accession number for the 16S rRNA gene sequence of strain MA1-6 ${ }^{\top}$ is $\mathrm{HQ852038.}$ was recently shown that Ruegeria pelagia is a later synonym of Ruegeria mobilis (Lai et al., 2010). At the time of writing, the genus Ruegeria thus comprised seven recognized species. In this study, we describe a Ruegeria-like bacterial strain, designated MA1-6 ${ }^{\mathrm{T}}$, which was isolated from a sea squirt (Halocynthia roretzi) collected from the South Sea, Korea, and establish its exact taxonomic position by using a polyphasic characterization that included determination of phenotypic properties and a detailed phylogenetic investigation based on $16 \mathrm{~S}$ rRNA gene sequences.

Strain MA1 $-6^{\mathrm{T}}$ was isolated by the standard dilution plating technique at $20{ }^{\circ} \mathrm{C}$ on marine agar 2216 (MA; Difco). The type strain (KCTC $12424^{\mathrm{T}}$ ) of Ruegeria atlantica, the type species of the genus Ruegeria, which was used as a reference strain for polar lipid analysis, was obtained from the Korean Collection for Type Cultures (KCTC), Daejeon, South Korea. The morphological, physiological and biochemical characteristics of strain MA1- $6^{\mathrm{T}}$ were investigated by using routine incubation on $\mathrm{MA}$ at $30^{\circ} \mathrm{C}$. Cell morphology was 
examined by light microscopy (E600; Nikon) and transmission electron microscopy (CM-20; Philips). The presence of flagella was examined by using transmission electron microscopy on cells from an exponentially growing culture. For this, cells were negatively stained with $1 \%(\mathrm{w} / \mathrm{v})$ phosphotungstic acid and the grids were examined after being air-dried. Growth at 4, 10, 15, 20, 25, 30, 37 and $40{ }^{\circ} \mathrm{C}$ was measured on MA. The Gram reaction was investigated by using the bioMérieux Gram stain kit according to the manufacturer's instructions. Growth under anaerobic conditions was determined after incubation in a Forma anaerobic chamber on MA and on MA supplemented with potassium nitrate $(0.1 \%, \mathrm{w} / \mathrm{v})$, both of which had been prepared anaerobically under a nitrogen atmosphere. The $\mathrm{pH}$ range for growth was determined in marine broth 2216 (MB; Difco) adjusted to $\mathrm{pH} 4.0-10.5$ (increments of $0.5 \mathrm{pH}$ units) by the addition of $\mathrm{HCl}$ and $\mathrm{Na}_{2} \mathrm{CO}_{3} ; \mathrm{pH}$ was verified after autoclaving. Growth in the absence of $\mathrm{NaCl}$ and in the presence of $0.5,1.0,2.0$ and $3.0 \%(\mathrm{w} / \mathrm{v}) \mathrm{NaCl}$ was investigated in trypticase soy broth prepared according to the formula of the Difco medium except that $\mathrm{NaCl}$ was excluded and that $0.45 \%(\mathrm{w} / \mathrm{v}) \mathrm{MgCl}_{2} \cdot 6 \mathrm{H}_{2} \mathrm{O}$ or $0.06 \%(\mathrm{w} /$ v) $\mathrm{KCl}$ was added. Growth in the presence of $2.0-10.0 \%$ $\mathrm{NaCl}$ (increments of $1.0 \%$ ) was investigated in MB. Catalase and oxidase activities were determined as described by Cowan \& Steel (1965). Hydrolysis of casein, starch, hypoxanthine, tyrosine and xanthine was tested on MA with the substrate concentrations described by Cowan \& Steel (1965). Nitrate reduction and hydrolysis of aesculin, gelatin, Tweens 20, 40, 60 and 80, and urea were investigated as described by Lányí (1987) with the modification that artificial seawater was used for the preparation of media. The artificial seawater contained (per litre distilled water) $23.6 \mathrm{~g}$ $\mathrm{NaCl}, 0.64 \mathrm{~g} \mathrm{KCl}, 4.53 \mathrm{~g} \mathrm{MgCl}_{2} \cdot 6 \mathrm{H}_{2} \mathrm{O}, 5.94 \mathrm{~g} \mathrm{MgSO}_{4} \cdot 7 \mathrm{H}_{2} \mathrm{O}$ and $1.3 \mathrm{~g} \mathrm{CaCl}_{2} \cdot 2 \mathrm{H}_{2} \mathrm{O}$ (Bruns et al., 2001). Acid production from carbohydrates was investigated as described by Leifson (1963). Utilization of various substrates for growth was tested according to Baumann \& Baumann (1981), after supplementation with $1 \%(\mathrm{v} / \mathrm{v})$ vitamin solution (Staley, 1968) and $2 \%(\mathrm{v} / \mathrm{v})$ Hutner's mineral salts (Cohen-Bazire et al., 1957). Susceptibility to various antibiotics was determined on MA plates by using discs containing polymyxin B (100 U), streptomycin $(50 \mu \mathrm{g})$, penicillin $\mathrm{G}(20 \mathrm{U})$, chloramphenicol $(100 \mu \mathrm{g})$, ampicillin $(10 \mu \mathrm{g})$, cephalothin $(30 \mu \mathrm{g})$, gentamicin $(30 \mu \mathrm{g})$, novobiocin $(5 \mu \mathrm{g})$, tetracycline $(30 \mu \mathrm{g})$, kanamycin $(30 \mu \mathrm{g})$, lincomycin $(15 \mu \mathrm{g})$, oleandomycin $(15 \mu \mathrm{g})$, neomycin $(30 \mu \mathrm{g})$ or carbenicillin $(100 \mu \mathrm{g})$. Enzyme activities and other physiological properties were determined by using the API ZYM and API 20E systems (bioMérieux).

Cell biomass of strain MA1- $6^{\mathrm{T}}$ for chromosomal DNA extraction and for analyses of isoprenoid quinones and polar lipids, and cell biomass of Ruegeria atlantica KCTC $12424^{\mathrm{T}}$ for polar lipid analysis were obtained from cultures grown for 3 days in $\mathrm{MB}$ at $30{ }^{\circ} \mathrm{C}$. Chromosomal DNA was extracted and purified according to the method described by Yoon et al. (1996), with the modification that RNase $\mathrm{T} 1$ was used in combination with RNase A to minimize contamination of RNA. The 16S rRNA gene was amplified by PCR as described previously (Yoon et al., 1998) by using two universal primers (5'-GAGTTTGATCCTGGCTCAG$3^{\prime}$ and $5^{\prime}$-AGAAAGGAGGTGATCCAGCC-3'). Sequencing of the amplified 16S rRNA gene and phylogenetic analysis were performed as described by Yoon et al. (2003). The DNA $\mathrm{G}+\mathrm{C}$ content was determined according to the method of Tamaoka \& Komagata (1984), with the modification that the DNA was hydrolysed and the resultant nucleotides were analysed by reversed-phase HPLC.

Isoprenoid quinones were extracted and analysed as described by Komagata \& Suzuki (1987), by using reversedphase HPLC and a YMC ODS-A $(250 \times 4.6 \mathrm{~mm})$ column. For analysis of cellular fatty acids, cell mass of strain MA1-6 ${ }^{\mathrm{T}}$ was harvested from MA plates after incubation for 3 days at $30{ }^{\circ} \mathrm{C}$. Fatty acids were saponified, methylated and extracted by using the standard MIDI protocol (Sherlock Microbial Identification System, version 4.0). Fatty acids were analysed by GC (Hewlett Packard 6890) and were identified by using the TSBA40 database of the Microbial Identification System (Sasser, 1990). Polar lipids were extracted according to the procedures described by Minnikin et al. (1984) and were identified by two-dimensional TLC followed by spraying with molybdophosphoric acid, molybdenum blue, ninhydrin and $\alpha$-naphthol reagents (Minnikin et al., 1984; Komagata \& Suzuki, 1987), and Dragendorff's reagent (Sigma).

The morphological, cultural, physiological and biochemical characteristics of strain MA1-6 ${ }^{T}$ are given in the species description below and in Table 1. The almost-complete $16 \mathrm{~S}$ rRNA gene sequence of strain MA1- $6^{\mathrm{T}}$ comprised $1386 \mathrm{nt}$. In the neighbour-joining phylogenetic tree based on $16 \mathrm{~S}$ rRNA gene sequences, strain MA1- $6^{\mathrm{T}}$ formed a distinct evolutionary lineage within the cluster comprising Ruegeria species (Fig. 1). Strain MA1-6 ${ }^{\mathrm{T}}$ exhibited 16S rRNA gene sequence similarity of $95.3-96.5 \%$ to the type strains of recognized Ruegeria species and less than $95.1 \%$ to the type strains of other species used in this study. The predominant isoprenoid quinone detected in strain MA1- $6^{\mathrm{T}}$ was ubiquinone-10 (Q-10), as with members of the genus Ruegeria (Yi et al., 2007; Muramatsu et al., 2007). The fatty acid profile of strain MA1- $6^{\mathrm{T}}$ is shown in Table 2, together with those of the type strains of Ruegeria species analysed under identical conditions and using the same methods (Oh et al., 2011). The major fatty acid found in strain MA1- $6^{\mathrm{T}}$ was $\mathrm{C}_{18: 1} \omega 7 c$, which is consistent with data for Ruegeria species and the vast majority of members of the Alphaproteobacteria. The fatty acid profile of strain MA1- $6^{\mathrm{T}}$ was similar to those of the type strains of Ruegeria species, although there were differences in the proportions of some components (Table 2). The polar lipid profile of strain MA1- $6^{\mathrm{T}}$ was compared with that of Ruegeria atlantica KCTC $12424^{\mathrm{T}}$, which was grown and analysed under identical conditions (Fig. 2). The polar lipid profile of strain MA1-6 ${ }^{\mathrm{T}}$ was similar to that of Ruegeria atlantica KCTC $12424^{\mathrm{T}}$ in that phosphatidylcholine, phosphatidylglycerol, an unidentified aminolipid and an unidentified lipid are major components and minor amounts of diphosphatidylglycerol and unidentified lipids are present 


\section{Table 1. Differential phenotypic characteristics of strain MA1-6 ${ }^{\top}$ and the type strains of related Ruegeria species}

Strains: 1, MA1-6 ${ }^{\mathrm{T}} ; 2$, Ruegeria atlantica KCTC $12424^{\mathrm{T}}$ (data from Rüger \& Höfle, 1992; Oh et al., 2011); 3, Ruegeria lacuscaerulensis KCTC 2953 ${ }^{\mathrm{T}}$ (Petursdottir \& Kristjansson, 1997; Oh et al., 2011); 4, Ruegeria mobilis CIP 109181 ${ }^{\mathrm{T}}$ (Muramatsu et al., 2007; Oh et al., 2011); 5, Ruegeria pomeroyi DSM $15171^{\mathrm{T}}$ (González et al., 2003; Oh et al., 2011); 6, Ruegeria scottomollicae CCUG 55858 ${ }^{\mathrm{T}}$ (Vandecandelaere et al., 2008; Oh et al., 2011). All strains are positive for activity of oxidase and catalase, utilization of ${ }^{\star} \mathrm{D}$-glucose, acetate and L-malate, acid production from ${ }^{\star} \mathrm{D}$-ribose, and activity of $^{\star}$ alkaline phosphatase. All strains are weakly positive for activity of ${ }^{\star}$ esterase (C4). All strains are negative for Gram staining, utilization of ${ }^{\star}$ sucrose, trehalose, maltose, benzoate, salicin, formate and L-glutamate, acid production from ${ }^{\star}$ melezitose, lactose and raffinose, and activity of ${ }^{\star}$ lipase (C14), valine arylamidase, cystine arylamidase, trypsin, $\alpha$-chymotrypsin, naphthol-AS-BI-phosphohydrolase, $\alpha$-galactosidase, $\beta$ glucuronidase, $\beta$-glucosidase, $N$-acetyl- $\beta$-glucosaminidase, $\alpha$-mannosidase and $\alpha$-fucosidase. $\mathrm{W}$, Weakly positive.

\begin{tabular}{|c|c|c|c|c|c|c|}
\hline Characteristic & 1 & 2 & 3 & 4 & 5 & 6 \\
\hline \multicolumn{7}{|l|}{ Growth at: } \\
\hline $40{ }^{\circ} \mathrm{C}$ & - & - & + & - & + & $\mathrm{w}$ \\
\hline Motility & - & - & - & + & + & + \\
\hline Anaerobic growth & $-1+\dagger$ & - & - & $+\ddagger$ & - & $-\ddagger$ \\
\hline \multicolumn{7}{|l|}{ Hydrolysis of: } \\
\hline Aesculin & - & + & - & + & - & + \\
\hline Xanthine & + & + & + & $-{ }^{*}$ & + & $-*$ \\
\hline Tween 80 & - & - & - & - & - & + \\
\hline \multicolumn{7}{|l|}{ Utilization of: ${ }^{*}$} \\
\hline L-Arabinose & - & - & - & + & - & - \\
\hline D-Xylose & - & + & - & + & + & + \\
\hline Citrate & $\mathrm{w}$ & + & + & - & + & + \\
\hline Pyruvate & - & + & + & + & + & + \\
\hline Succinate & + & + & + & + & - & + \\
\hline \multicolumn{7}{|l|}{ Acid production from:* } \\
\hline L-Arabinose & - & + & - & + & - & + \\
\hline Cellobiose & - & + & - & + & - & + \\
\hline D-Fructose & - & - & $\mathrm{w}$ & + & - & + \\
\hline D-Galactose & + & + & - & - & - & + \\
\hline D-Glucose & + & - & - & $\mathrm{W}$ & - & + \\
\hline myo-Inositol & - & - & - & + & - & + \\
\hline Trehalose & - & + & - & $\mathrm{W}$ & - & + \\
\hline D-Xylose & - & + & - & $\mathrm{w}$ & + & + \\
\hline \multicolumn{7}{|l|}{ Enzyme activity (API ZYM)* } \\
\hline Esterase lipase (C8) & + & - & $\mathrm{W}$ & - & $\mathrm{w}$ & - \\
\hline Leucine arylamidase & + & $\mathrm{w}$ & $\mathrm{W}$ & $\mathrm{W}$ & + & $\mathrm{w}$ \\
\hline Acid phosphatase & + & - & - & - & - & - \\
\hline$\beta$-Galactosidase & - & - & + & - & - & - \\
\hline$\alpha$-Glucosidase & + & - & - & - & - & - \\
\hline DNA G $+\mathrm{C}$ content $(\mathrm{mol} \%)$ & 58.6 & 55 & 66.2 & 58.5 & $67.9-68.1$ & 61 \\
\hline
\end{tabular}

${ }^{*}$ Data for reference strains are from Oh et al. (2011) and were obtained using the same methods and under the same conditions as the novel isolate. $\dagger$ Determined without/with nitrate.

$\ddagger$ Data from Oh et al. (2011); the result without and with nitrate. 


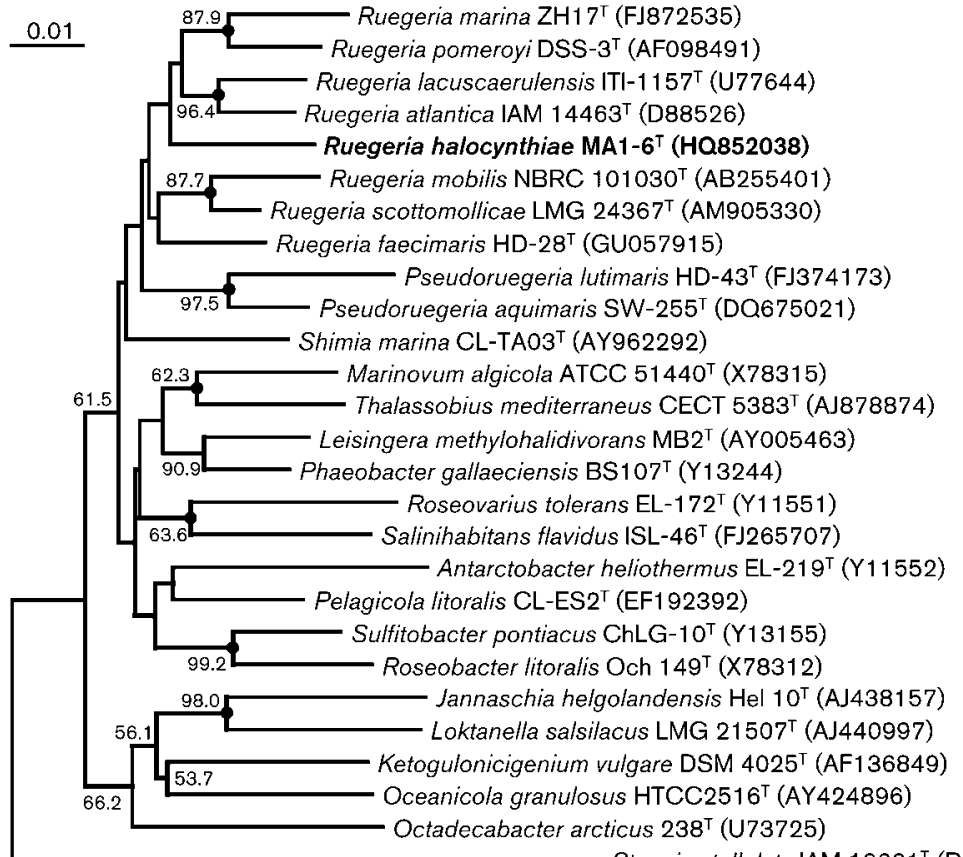

Stappia stellulata IAM $12621^{\top}$ (D88525)
Fig. 1. Neighbour-joining phylogenetic tree based on 16S rRNA gene sequences showing the position of strain MA1-6 ${ }^{\top}$ among recognized Ruegeria species and some other related taxa. Bootstrap values (expressed as percentages of 1000 replications) are shown at branch points; only values $>50 \%$ are shown. Filled circles indicate that the corresponding nodes were also recovered in the trees generated with the maximum-likelihood and maximum-parsimony algorithms. Stappia stellulata IAM $12621^{\top}$ was used as an outgroup. Bar, 0.01 substitutions per nucleotide position.
Table 2. Cellular fatty acid compositions (\%) of strain MA1-6 ${ }^{\top}$ and the type strains of related Ruegeria species

Strains: 1, MA1-6 $6^{\mathrm{T}} ; 2$, Ruegeria atlantica KCTC $12424^{\mathrm{T}} ; 3$, Ruegeria lacuscaerulensis KCTC $2953^{\mathrm{T}}$; 4, Ruegeria mobilis CIP $109181^{\mathrm{T}}$; 5, Ruegeria pomeroyi DSM $15171^{\mathrm{T}}$; 6 , Ruegeria scottomollicae CCUG $55858^{\mathrm{T}}$. Data for the reference strains are from Oh et al. (2011) and were obtained under the same conditions and using the same methods as the novel isolate. Fatty acids that represent $<0.5 \%$ in all strains were omitted. -, Not detected.

\begin{tabular}{|lcccccc|}
\hline Fatty acid & $\mathbf{1}$ & $\mathbf{2}$ & $\mathbf{3}$ & $\mathbf{4}$ & $\mathbf{5}$ & $\mathbf{6}$ \\
\hline Straight-chain & & & & & & \\
$\mathrm{C}_{10: 0}$ & 3.0 & 2.6 & 6.3 & - & 2.8 & - \\
$\mathrm{C}_{12: 0}$ & 2.9 & 3.1 & 4.5 & - & 1.2 & 0.1 \\
$\mathrm{C}_{16: 0}$ & 4.6 & 3.6 & 1.8 & 5.3 & 8.2 & 2.5 \\
$\mathrm{C}_{18: 0}$ & 1.1 & 0.6 & 2.0 & 1.5 & 2.0 & 0.6 \\
Unsaturated & & & & & & \\
$\mathrm{C}_{17: 1} \omega 7 c$ & 0.4 & - & - & 0.5 & 0.4 & 1.0 \\
$\mathrm{C}_{18: 1} \omega 7 c$ & 54.4 & 63.5 & 69.8 & 74.1 & 66.7 & 79.1 \\
$\mathrm{C}_{20: 1} \omega 7 c$ & - & 0.3 & 0.8 & 0.3 & 0.4 & 0.3 \\
Hydroxy $_{\mathrm{C}_{10: 0} 3-\mathrm{OH}}$ & & & & & & \\
$\mathrm{C}_{12: 0} 3-\mathrm{OH}$ & 4.8 & 5.2 & 7.5 & 0.8 & 6.1 & 0.3 \\
$\mathrm{C}_{16: 0} 2-\mathrm{OH}$ & 11.1 & 6.9 & - & 5.9 & 5.2 & 4.3 \\
$\mathrm{C}_{18: 1} 2-\mathrm{OH}$ & 0.5 & 1.2 & - & 1.1 & 0.2 & 3.0 \\
11-Methyl-C $_{18: 1} \omega 7 c$ & 16.1 & 11.3 & 1.8 & 4.2 & 5.4 & 2.5 \\
Cyclo $\mathrm{C}_{19: 0} \omega 8 c$ & - & - & 0.6 & - & - & - \\
Unknown ECL $11.799^{*}$ & 0.8 & 0.2 & 1.2 & 3.0 & 0.1 & 2.5 \\
\hline
\end{tabular}

${ }^{\star} \mathrm{ECL}$, equivalent chain-length.
(Fig. 2). The DNA G+C content of strain MA1-6 ${ }^{\mathrm{T}}$ was $58.6 \mathrm{~mol} \%$. The results obtained from the chemotaxonomic analyses are sufficient to support the result of the phylogenetic analysis based on 16S rRNA gene sequences, suggesting that strain MA1- $6^{\mathrm{T}}$ may be a member of the genus Ruegeria.

Strain MA1- $6^{\mathrm{T}}$ was clearly distinguishable from recognized Ruegeria species based on differences in several phenotypic characteristics, most of which were determined under the same conditions and methods in our laboratory (Table 1). The phylogenetic distinctiveness and differential phenotypic properties of strain MA1-6 $6^{\mathrm{T}}$ were sufficient to show that it represents a species that is separate from recognized species of the genus Ruegeria (Stackebrandt \& Goebel, 1994). Therefore, on the basis of the data presented, strain MA1 $-6^{\mathrm{T}}$ is considered to represent a novel species of the genus Ruegeria, for which the name Ruegeria halocynthiae sp. nov. is proposed.

\section{Description of Ruegeria halocynthiae sp. nov.}

Ruegeria halocynthiae (ha.lo.cyn.thi'a.e. N.L. gen. n. halocynthiae of Halocynthia, named after the generic name of the sea squirt Halocynthia roretzi, from which the type strain was isolated).

Cells are Gram-negative, non-motile rods, $0.2-0.6 \times 1.0-$ $10.0 \mu \mathrm{m}$ in size; a few cells longer than $10.0 \mu \mathrm{m}$ may occur. Colonies on MA are circular to slightly irregular, flat, glistening, smooth, cream-coloured and $2.0-3.0 \mathrm{~mm}$ in diameter after incubation for 3 days at $30{ }^{\circ} \mathrm{C}$. Anaerobic growth does not occur on MA but does occur on MA supplemented with nitrate. Optimal growth occurs at $30{ }^{\circ} \mathrm{C}$; growth occurs at 10 and $37{ }^{\circ} \mathrm{C}$ but not at 4 or $40{ }^{\circ} \mathrm{C}$. Optimal pH for growth is between 7.0 and 8.0; growth 

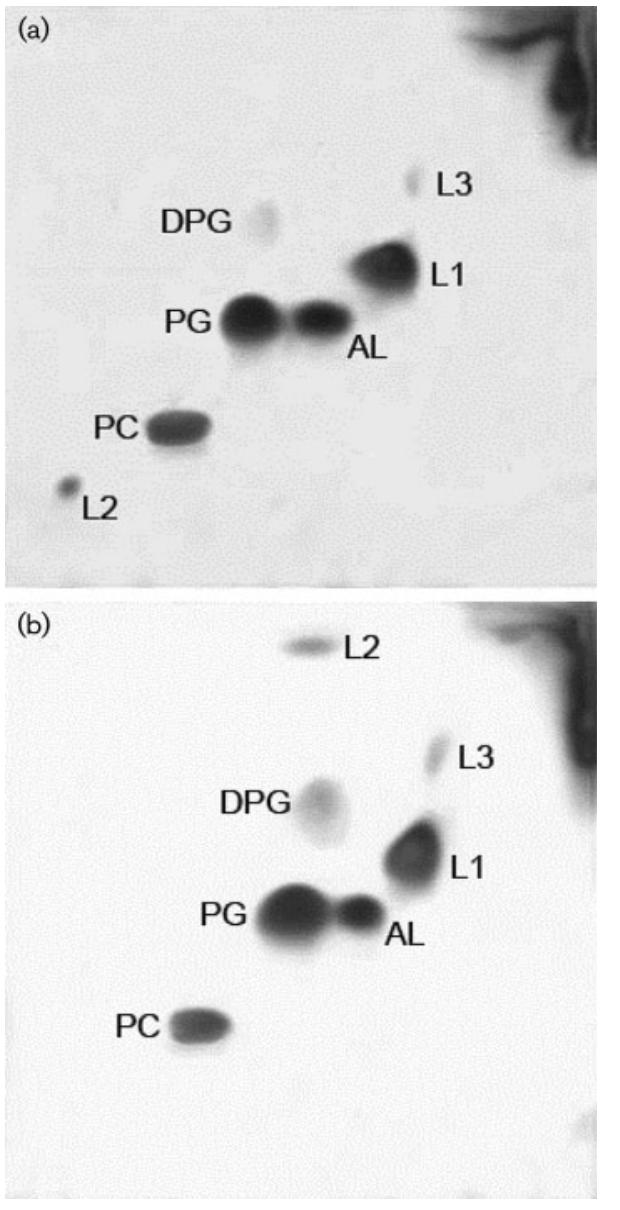

Fig. 2. TLCs of polar lipids of strain $M A 1-6^{\top}$ (a) and Ruegeria atlantica KCTC $12424^{\top}$ (b). PC, Phosphatidylcholine; PG, phosphatidylglycerol; DPG, diphosphatidylglycerol; AL, unidentified aminolipid; L1-3, unidentified lipids.

occurs at $\mathrm{pH} 5.5$ but not at $\mathrm{pH}$ 5.0. Optimal growth occurs in the presence of $2-3 \%(\mathrm{w} / \mathrm{v}) \mathrm{NaCl}$; growth occurs in the presence of $6.0 \%(\mathrm{w} / \mathrm{v}) \mathrm{NaCl}$ but not in the absence of $\mathrm{NaCl}$ or in the presence of more than $7.0 \%(\mathrm{w} / \mathrm{v}) \mathrm{NaCl}$. Nitrate reduction is positive. Hydrolyses hypoxanthine, L-tyrosine and xanthine, but not aesculin, casein, gelatin, starch, Tween 80 or urea. Utilizes cellobiose, D-galactose, D-glucose, Dmannose, acetate, citrate (weakly), L-malate and succinate as carbon and energy sources, but not L-arabinose, D-fructose, maltose, sucrose, trehalose, D-xylose, benzoate, formate, pyruvate, salicin or L-glutamate. Acid is produced from Dgalactose, D-glucose, D-mannose and D-ribose, but not from L-arabinose, cellobiose, D-fructose, myo-inositol, lactose, maltose, D-mannitol, melezitose, melibiose, raffinose, Lrhamnose, D-sorbitol, sucrose, trehalose or D-xylose. Susceptible to ampicillin, carbenicillin, cephalothin, chloramphenicol, gentamicin, neomycin, penicillin $\mathrm{G}$ and polymyxin $\mathrm{B}$, but not to kanamycin, lincomycin, novobiocin, oleandomycin, streptomycin or tetracycline. In assays with the API ZYM system, positive for alkaline phosphatase, esterase lipase
(C8), leucine arylamidase, acid phosphatase and $\alpha$-glucosidase, weakly positive for esterase (C4), but negative for lipase (C14), valine arylamidase, cystine arylamidase, trypsin, $\alpha$ chymotrypsin, naphthol-AS-BI-phosphohydrolase, $\alpha$-galactosidase, $\beta$-galactosidase, $\beta$-glucuronidase, $\beta$-glucosidase, $N$-acetyl- $\beta$-glucosaminidase, $\alpha$-mannosidase and $\alpha$-fucosidase. The predominant ubiquinone is $\mathrm{Q}-10$. The major fatty acid ( $>10 \%$ of the total) is $\mathrm{C}_{18: 1} \omega 7 \mathrm{c}$. The major polar lipids are phosphatidylcholine, phosphatidylglycerol, an unidentified aminolipid and an unidentified lipid.

The type strain, MA1- $6^{\mathrm{T}}\left(=\right.$ KCTC $23463^{\mathrm{T}}=$ CCUG $\left.60744^{\mathrm{T}}\right)$, was isolated from a sea squirt (Halocynthia roretzi) collected in the South Sea, Korea. The DNA G + C content of the type strain is $58.6 \mathrm{~mol} \%$ (determined by HPLC).

\section{Acknowledgements}

This work was supported by a grant from the National Fisheries Research and Development Institute (NFRDI) and the 21C Frontier Program of Microbial Genomics and Applications (grant 11-2008-00002-00) from the Ministry of Education, Science \& Technology (MEST) of the Republic of Korea.

\section{References}

Arahal, D. R., Macián, M. C., Garay, E. \& Pujalte, M. J. (2005). Thalassobius mediterraneus gen. nov., sp. nov., and reclassification of Ruegeria gelatinovorans as Thalassobius gelatinovorus comb. nov. Int J Syst Evol Microbiol 55, 2371-2376.

Baumann, P. \& Baumann, L. (1981). The marine Gram-negative eubacteria: genera Photobacterium, Beneckea, Alteromonas, Pseudomonas, and Alcaligenes. In The Prokaryotes, pp. 1302-1331. Edited by M. P. Starr, H. Stolp, H. G. Trüper, A. Balows \& H. G. Schlegel. Berlin: Springer.

Bruns, A., Rohde, M. \& Berthe-Corti, L. (2001). Muricauda ruestringensis gen. nov., sp. nov., a facultatively anaerobic, appendaged bacterium from German North Sea intertidal sediment. Int $J$ Syst Evol Microbiol 51, 1997-2006.

Cohen-Bazire, G., Sistrom, W. R. \& Stanier, R. Y. (1957). Kinetic studies of pigment synthesis by nonsulfur purple bacteria. J Cell Comp Physiol 49, 25-68.

Cowan, S. T. \& Steel, K. J. (1965). Manual for the Identification of Medical Bacteria. London: Cambridge University Press.

González, J. M., Covert, J. S., Whitman, W. B., Henriksen, J. R., Mayer, F., Scharf, B., Schmitt, R., Buchan, A., Fuhrman, J. A. \& other authors (2003). Silicibacter pomeroyi sp. nov. and Roseovarius nubinhibens sp. nov., dimethylsulfoniopropionate-demethylating bacteria from marine environments. Int J Syst Evol Microbiol 53, 1261-1269.

Huo, Y.-Y., Xu, X.-W., Li, X., Liu, C., Cui, H.-L., Wang, C.-S. \& Wu, M. (2011). Ruegeria marina sp. nov., isolated from marine sediment. Int J Syst Evol Microbiol 61, 347-350.

Komagata, K. \& Suzuki, K. (1987). Lipids and cell-wall analysis in bacterial systematics. Methods Microbiol 19, 161-207.

Lai, Q., Yuan, J., Li, F., Zheng, T. \& Shao, Z. (2010). Ruegeria pelagia is a later heterotypic synonym of Ruegeria mobilis. Int J Syst Evol Microbiol 60, 1918-1920.

Lányi, B. (1987). Classical and rapid identification methods for medically important bacteria. Methods Microbiol 19, 1-67. 
Lee, K., Choo, Y.-J., Giovannoni, S. J. \& Cho, J.-C. (2007). Ruegeria pelagia sp. nov., isolated from the Sargasso Sea, Atlantic Ocean. Int J Syst Evol Microbiol 57, 1815-1818.

Leifson, E. (1963). Determination of carbohydrate metabolism of marine bacteria. J Bacteriol 85, 1183-1184.

Martens, T., Heidorn, T., Pukall, R., Simon, M., Tindall, B. J. \& Brinkhoff, T. (2006). Reclassification of Roseobacter gallaeciensis Ruiz-Ponte et al. 1998 as Phaeobacter gallaeciensis gen. nov., comb. nov., description of Phaeobacter inhibens sp. nov., reclassification of Ruegeria algicola (Lafay et al. 1995) Uchino et al. 1999 as Marinovum algicola gen. nov., comb. nov., and emended descriptions of the genera Roseobacter, Ruegeria and Leisingera. Int J Syst Evol Microbiol 56, 1293-1304.

Minnikin, D. E., O'Donnell, A. G., Goodfellow, M., Alderson, G., Athalye, M., Schaal, A. \& Parlett, J. H. (1984). An integrated procedure for the extraction of bacterial isoprenoid quinones and polar lipids. J Microbiol Methods 2, 233-241.

Muramatsu, Y., Uchino, Y., Kasai, H., Suzuki, K. \& Nakagawa, Y. (2007). Ruegeria mobilis sp. nov., a member of the Alphaproteobacteria isolated in Japan and Palau. Int J Syst Evol Microbiol 57, 1304-1309.

Oh, K.-H., Jung, Y.-T., Oh, T.-K. \& Yoon, J.-H. (2011). Ruegeria faecimaris sp. nov., isolated from a tidal flat sediment. Int J Syst Evol Microbiol 61, 1182-1188.

Petursdottir, S. K. \& Kristjansson, J. K. (1997). Silicibacter lacuscaerulensis gen. nov., sp. nov., a mesophilic moderately halophilic bacterium characteristic of the Blue Lagoon geothermal lake in Iceland. Extremophiles 1, 94-99.

Rüger, H.-J. \& Höfle, M. G. (1992). Marine star-shaped-aggregateforming bacteria: Agrobacterium atlanticum sp. nov.; Agrobacterium meteori sp. nov.; Agrobacterium ferrugineum sp. nov., nom. rev.; Agrobacterium gelatinovorum sp. nov., nom. rev.; and Agrobacterium stellulatum sp. nov., nom. rev. Int J Syst Bacteriol 42, 133-143.

Sasser, M. (1990). Identification of bacteria by gas chromatography of cellular fatty acids, MIDI Technical Note 101. Newark, DE: MIDI Inc.
Stackebrandt, E. \& Goebel, B. M. (1994). Taxonomic note: a place for DNA-DNA reassociation and $16 \mathrm{~S}$ rRNA sequence analysis in the present species definition in bacteriology. Int J Syst Bacteriol 44, 846849.

Staley, J. T. (1968). Prosthecomicrobium and Ancalomicrobium: new prosthecate freshwater bacteria. J Bacteriol 95, 1921-1942.

Tamaoka, J. \& Komagata, K. (1984). Determination of DNA base composition by reversed-phase high-performance liquid chromatography. FEMS Microbiol Lett 25, 125-128.

Uchino, Y., Hirata, A., Yokota, A. \& Sugiyama, J. (1998). Reclassification of marine Agrobacterium species: proposals of Stappia stellulata gen. nov., comb. nov., Stappia aggregata sp. nov., nom. rev., Ruegeria atlantica gen. nov., comb. nov., Ruegeria gelatinovora comb. nov., Ruegeria algicola comb. nov., and Ahrensia kieliense gen. nov., sp. nov., nom. rev. J Gen Appl Microbiol 44, 201-210.

Vandecandelaere, I., Nercessian, O., Segaert, E., Achouak, W., Faimali, M. \& Vandamme, P. (2008). Ruegeria scottomollicae sp. nov., isolated from a marine electroactive biofilm. Int J Syst Evol Microbiol 58, 2726-2733.

Yi, H., Lim, Y. W. \& Chun, J. (2007). Taxonomic evaluation of the genera Ruegeria and Silicibacter: a proposal to transfer the genus Silicibacter Petursdottir and Kristjansson 1999 to the genus Ruegeria Uchino et al. 1999. Int J Syst Evol Microbiol 57, 815-819.

Yoon, J.-H., Kim, H., Kim, S.-B., Kim, H.-J., Kim, W. Y., Lee, S. T., Goodfellow, M. \& Park, Y.-H. (1996). Identification of Saccharomonospora strains by the use of genomic DNA fragments and rRNA gene probes. Int J Syst Bacteriol 46, 502-505.

Yoon, J.-H., Lee, S. T. \& Park, Y.-H. (1998). Inter- and intraspecific phylogenetic analysis of the genus Nocardioides and related taxa based on 16S rDNA sequences. Int J Syst Bacteriol 48, 187-194.

Yoon, J.-H., Kang, K. H. \& Park, Y.-H. (2003). Psychrobacter jeotgali sp. nov., isolated from jeotgal, a traditional Korean fermented seafood. Int J Syst Evol Microbiol 53, 449-454. 